\title{
The early impact of initiatives to close attainment gaps at UCL
}

Rosalind Duhs, Julie Evans, Paulette Williams, Parama Chaudhury

University College London

\begin{abstract}
This article provides an overview of core aspects of efforts to close the black, Asian and minority ethnic (BAME) attainment gap across University College London (UCL). Although the main 'Catalyst Student Success' project focuses on home undergraduate students, at UCL we are also using similar approaches to enhance inclusivity in postgraduate courses. The focus in this paper is nevertheless on undergraduates. The detailed use of student attainment data by the UCL Centre for Teaching and Learning Economics is outlined and discussed to underpin the introduction of the use of UCL's 'Inclusive Curriculum Health Check' (ICHC) - UCL BAME Attainment Project 2018 - as a framework for the initiatives taken by departments. A table with the initial responses from the departments in one faculty is presented and selected points are discussed. The value and potential of the initiatives recommended through the $\mathrm{ICHC}$ are explored in a table which links systematic review evidence (Schneider and Preckel, 2017) to the ICHC. Staff actions in partnership with students are designed primarily to have a positive impact on the experience and outcomes of BAME students, but the research evidence suggests that favourable effects will accrue for all students.
\end{abstract}

\section{Introduction}

This introduction starts with an outline of UCL's initial engagement and its significance. The official launch of the 'Catalyst Student Success' BAME attainment gap project at University College London (UCL) was marked by a one-day 'BME Attainment Conference' on 10 April 2018. Staff from across the University participated. The University has around 19,000 undergraduate students, 15,000 postgraduate taught students and 4,200 academic and teaching staff.

As late project joiners, UCL benefited from the ground-breaking work done by BAME Attainment Gap Project participants elsewhere, especially Kingston and De Montfort Universities. UCL has adopted the whole-institution approach to closing attainment gaps, as advocated by McDuff et al.(2018) and taken initiatives informed by Kingston's Inclusive Curriculum Framework (ICF).

The value-added (VA) metric initiated by Kingston, whereby the probability of students gaining a first-class or upper-second degree is calculated in relation to qualifications on entry and subject choice, has been helpful to universities where qualifications vary. The VA metric has facilitated the deep analysis and use of the data as a catalyst for action at other universities such as Kingston. The detailed analytical work carried out by Economics at UCL - based on the Oaxaca-Blinder decomposition technique applied to student degree classifications - is explored here. 
McDuff (2019) points out that 'in 2016/17, for qualifiers in undergraduate degrees, the BAME attainment gap was $13.6 \%$ and a shocking $24.1 \%$ for black students'. BAME student outcomes at UCL are affected by the comparatively high tariff for student admission (offers in the range $A^{*} A^{*} A$ to $A B B$ ) so the VA data which accounts for entry tariffs is not useful. ${ }^{1}$ However, there are documented attainment gaps between BAME students and other students at UCL. In $2017-18,95.7 \%$ of white students and $91.8 \%$ of BAME students achieved a good degree (either a 1 st or 2.1 ), so overall there is a gap of $3.9 \%$ on average. Gaps naturally vary across the institution, as reflected in the analysis carried out by Economics (see Figure 1). Some faculties are small, affecting reliability. The School of Slavonic and East European Studies (SSEES) has a gap of $-4 \%$ with BAME students outperforming white students, although, as numbers here are low, this figure is not statistically significant. At the other end of the scale, there is an attainment gap of $18 \%$ in the Faculty of the Built Environment.

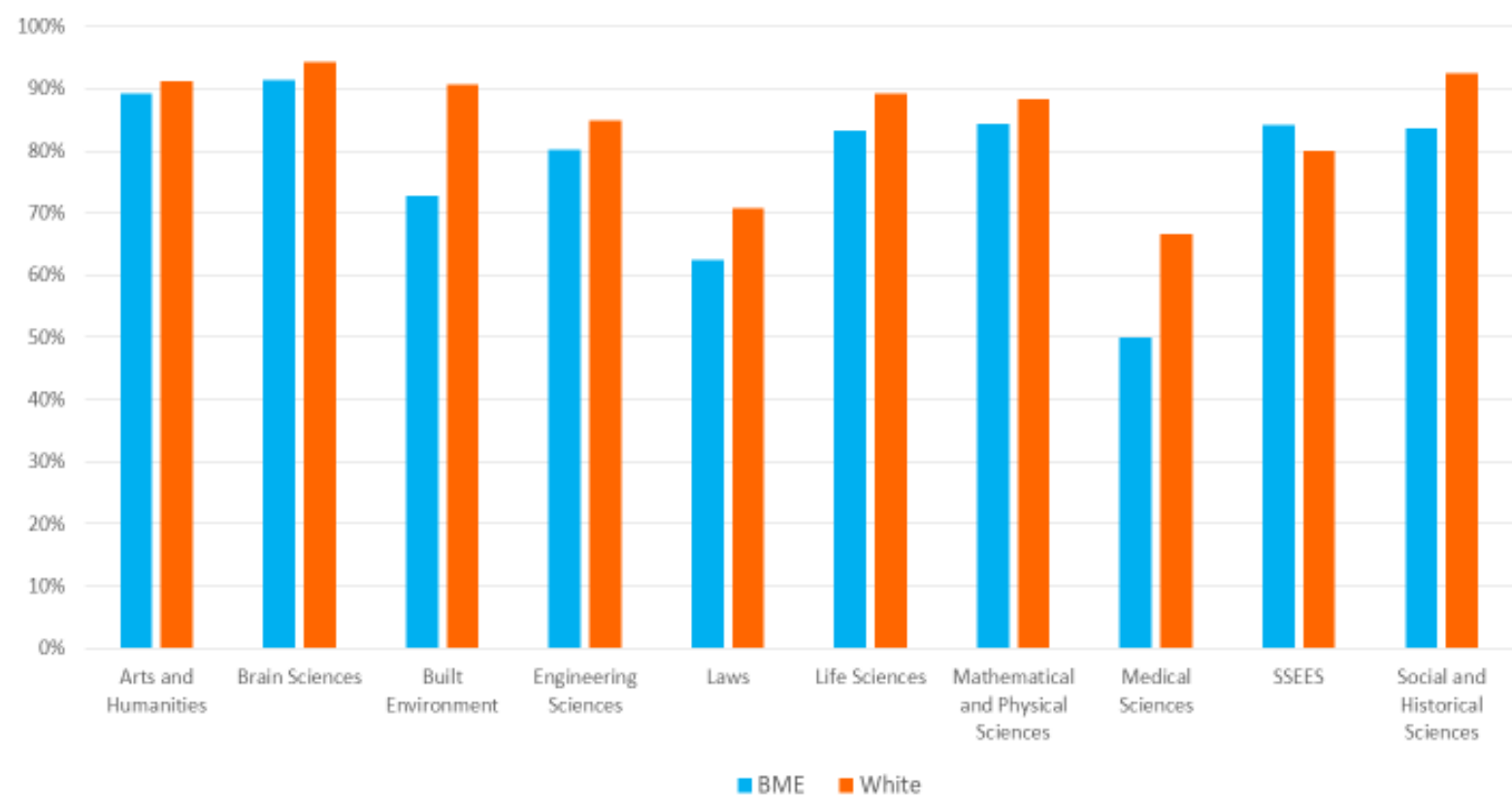

Figure 1. Choice of Programme 2017-18: \% of 2.1s or 1sts by UCL faculty. (Chaudhury et al., 2019)

\section{Analysing BAME attainment at UCL}

The UCL Centre for Teaching and Learning Economics, Department of Economics, decided to drill down into graduate degree class outcomes data at UCL. The researchers were interested in learning more about the BAME attainment gap and wanted to find out how it varied over different groups and to attempt to identify the main reasons for the gap. They surmised that, if department and degree choice, UCAS tariffs, and parental/household characteristics were comparable, the unexplained part of the attainment gap might partly be caused by 'discrimination'. They measured possible discrimination using the Oaxaca-Blinder

\footnotetext{
${ }^{1}$ The VA metric looks at the gap in average marks conditioning only on entry qualifications and departments or programmes. The UCL analysis broadens this to look at the probability of acquiring a particular class of degree (which arguably matters more than the specific mark both for jobs and for further study) and condition on a wider array of factors such as parental occupation, disability status and gender which significantly affect attainment.
} 
decomposition technique ${ }^{2}$. The ultimate aim was to ensure that policy implications were thoroughly understood and actions planned in the light of insights gained.

Table 1 shows the overall results of the analysis, separating out the raw gap in the percentage of white and BAME students respectively gaining a 2.1/1st into discrete proportions explained by department/programme, UCAS tariffs on entry, gender etc. (see Figure 2) and then comparing it with the part of the gap not explained by any of these.

It is important to note that the percentage characterised as 'discrimination' - the unexplained part of the gap - is larger for a $1^{\text {st }}$ than for a 2.1. The results of this study 'imply that after controlling for differences in observed characteristics, BAME students should actually have a larger probability of getting a $1^{\text {st }}$, and therefore being eligible to enter higher degree programmes' (Chaudhury et al., 2019). (Higher degrees are Master's and PhD.s). Graduates with first-class degrees are more likely to embark on higher degrees and enter academia. A recent report by Advance HE (Adams, 2018) stated that, in 2016-17, only $0.6 \%$ of UK professors were black. This is disquieting not only because it may be a sign of discrimination, but also because it means that BAME students lack role models.

Table 1. Probability of getting a 2.1 or a $1^{\text {st }}$ (Chaudhury et al., 2019)

\begin{tabular}{|l|c|}
\hline \multicolumn{2}{|c|}{ Probability of getting a 2.1 } \\
\hline $\begin{array}{l}\text { Total gap between white and BAME } \\
\text { students }\end{array}$ & $6.5 \%$ \\
\hline Explained part of the gap & $0.5 \%$ \\
\hline Unexplained part of the gap & $6 \%$ \\
\hline \multicolumn{2}{|c|}{ Probability of getting a 1st } \\
\hline $\begin{array}{l}\text { Total gap between white and BAME } \\
\text { students }\end{array}$ & $5.4 \%$ \\
\hline Explained part of the gap & $3.4 \%$ \\
\hline Unexplained part of the gap & $8.8 \%$ \\
\hline
\end{tabular}

As mentioned above, McDuff (op. cit.) highlights the $24.1 \%$ attainment gap for black students. Chaudhury et al. (op. cit.) underline the larger attainment gap amongst black students in comparison to Asian students (see Figure 2). Even though the total gap is larger for black students, the unexplained part is proportionally larger for Asian students.

\footnotetext{
2 The Blinder Oaxaca decomposition technique is widely used to identify and quantify the separate contributions of group differences in measurable characteristics, such as education... to racial and gender gaps in outcomes. (Fairlie, 2003). See also the World Bank's explanation.
} 


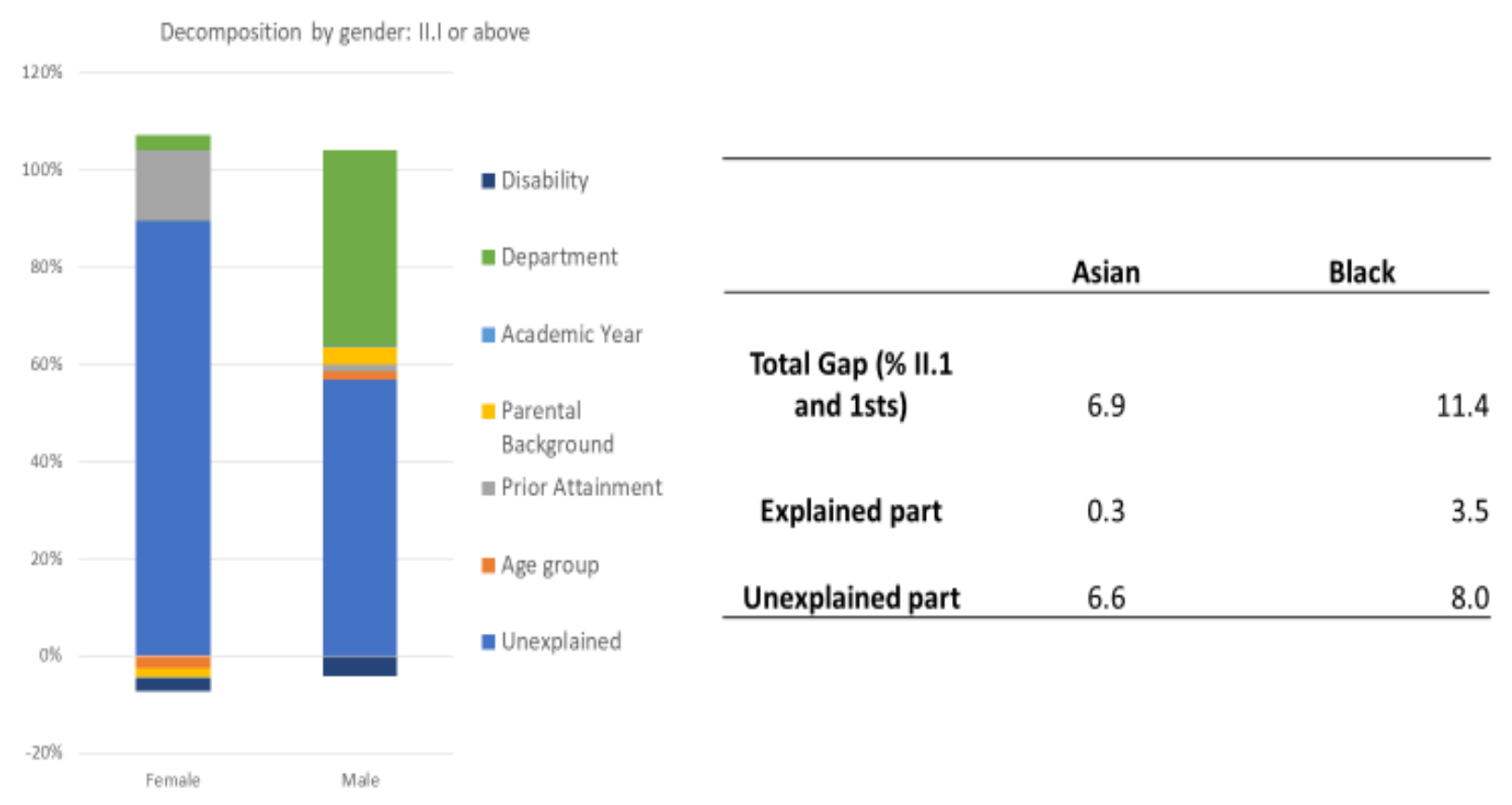

Figure 2. How does the decomposition vary by ethnicity? (Chaudhury et al., op. cit.)

It is evident from Chaudhury et al.'s (op.cit.) detailed analysis that there is a lot of work to be done at UCL, even if the overall attainment gap does not appear to be large at first sight. We now focus on some of the strategies which have been adopted at UCL and then explore a quantitative meta-analysis. The meta-analysis confirms that the approaches which originate in Kingston's successful ICF, adapted for integration with UCL's annual quality assurance (QA) cycle, have every chance of exerting a positive impact on BAME attainment.

\section{Strategies to close the BAME attainment gap: Quality Assurance}

McDuff (op.cit.) recommended an institution-wide approach to closing the BAME attainment gap. UCL's efforts to close the attainment gap have been thoroughly integrated into the UCL quality assurance and enhancement cycle. A cornerstone of this process is the 'Annual Student Experience Review' (ASER) (Owen, 2015), completed by departments. In the 201718 ASER report, departments were asked to evaluate their progress towards the goals of the inclusive curriculum, through the 'Inclusive Curriculum Health Check' (ICHC), which constituted a major step towards enhancing the experience of black, Asian and minority students. This was a mandatory part of QA at UCL and outcomes were discussed by the Quality Review Subcommittee, Education Committee and Faculty Tutor Forum and were also circulated to Deans and Faculty leadership teams through Race Equality Charter Mark work.

The ICF as approached by De Montfort was adapted by Julie Evans, project co-lead, to create the ICHC. The aim was to build up a snapshot of current practices. For this purpose, the checklist style approach was most appropriate, as it was straightforward for staff to use. The initial draft of the ICHC was circulated for comment to the BAME Attainment Gap working group, the UCL Arena Centre for research-based education, and the Vice Provost Education and Student Affairs and his office. Reponses to the ICHC are not benchmarked or moderated; they reflect departments' perspectives on their own curricula, teaching and assessment. 
The resulting set of criteria is provided in Table 2. Staff received the ICHC with their ASER forms; instructions were provided, inviting programme directors to map their current curriculum and learning activities as well as student support activities in relation to the extent of their engagement to the ICHC. Guidance was available from BAME project faculty leads, UCL Arena Centre Faculty Teaching Fellows, and BAME co-leads as needed.

Table 2 illustrates the outcome, providing the perceptions of eight departments in one randomly-selected faculty as to the extent of the inclusivity of their curricula measured against the ICHC criteria at the end of the 2017-18 academic year. The numbers in the table represent the total of departments in the sample faculty which selected the corresponding classification of engagement with the inclusive curriculum.

The ICHC reports were analysed and constructive feedback provided to each department. The level of detail supplied by most departments was impressive and the BAME project team was pleasantly surprised at the amount of inclusive activities currently in existence. Engagement with the student experience was for the most part profound. The numerical table (Table 2) cannot convey the detail provided, but it does serve to highlight some areas where more support will be needed.

Patterns emerged across the faculties. Perhaps most noticeable was the patchy involvement of students in 'the formative and summative annual review of your programme looking at content and attainment from an ethnic diversity perspective' (ICHC Question 13, Table 2). Other Catalyst projects have found student engagement extremely effective. As UCL has a well-developed 'ChangeMakers' initiative, which organises successful partnerships between students and staff, it should be possible to extend these to focus on steps to close the attainment gap. We are working with student curriculum partners, seeking out those from BAME groups to investigate their experience, using training materials and guidance based on the ICF.

Another area which is surprising is that - although it emerges from the $\mathrm{ICHC}$ responses to question 7 (Table 2) from UCL departments that a lot of group work takes place across faculties - very few departments consider the advantages of ethnically-diverse groups. Most respondents explain that they do not influence the composition of groups. We know that diverse groups work well (provided there is an appropriate ethnic diversity of students to allow this best practice). Sedghi and Rushworth (2017, p.10), for example, found that 'tutors should deliberately assign [students] to mixed groups rather than expect them to find their own group'.

A brief initial analysis of $\mathrm{ICHC}$ data has shown that students should be more closely involved in reviewing 'content and attainment from an ethnic diversity perspective' (ICHC Question 13, Table 2) and that the purposefully-diverse composition of groups (ICHC Question 7, Table 2) should be encouraged. A more detailed study of the data across all the faculties will enable project leads and each faculty lead to refine initiatives to support staff in their efforts to benefit BAME students. We plan to revisit and further develop the ICHC for the next iteration of ASER, drawing on expertise from the UCL Institute of Education. 
Table 2: Inclusive Curriculum Health Check Report 2017-18 - Perceptions of 8 departments in one Faculty

\begin{tabular}{|c|c|c|c|}
\hline Criteria & $\begin{array}{l}\text { Programme (s) } \\
\text { meets all criteria }\end{array}$ & $\begin{array}{l}\text { Programme }(\mathrm{s}) \\
\text { meets some } \\
\text { criteria }\end{array}$ & $\begin{array}{l}\text { No evidence on } \\
\text { our programme (s) }\end{array}$ \\
\hline $\begin{array}{l}\text { Content: to what extent does your programme } \\
\text { curriculum }\end{array}$ & \multicolumn{3}{|c|}{$\begin{array}{c}\text { Total number of departments to select each criterion } \\
\text { category }\end{array}$} \\
\hline $\begin{array}{l}\text { 1. create opportunities to discuss different } \\
\text { perspectives within and outside the UK } \\
\text { related to ethnic diversity? }\end{array}$ & 5 & 3 & \\
\hline $\begin{array}{l}\text { 2. use material that explores different data, } \\
\text { models and theories related to ethnic diversity } \\
\text { - even within a historical context? }\end{array}$ & 4 & 4 & \\
\hline $\begin{array}{l}\text { 3. have reading lists and resources that } \\
\text { contain a diverse range of authors including } \\
\text { those from different ethnicities, from outside } \\
\text { the UK and from non-academic sources } \\
\text { where relevant? }\end{array}$ & 3 & 5 & \\
\hline $\begin{array}{l}\text { 4. develop students' critical thinking and } \\
\text { awareness of different perspectives on issues } \\
\text { relating to diversity in ethnicity, culture and } \\
\text { nationality? }\end{array}$ & 5 & 3 & \\
\hline $\begin{array}{l}\text { 5. allow students to gain an understanding of } \\
\text { how different factors e.g. social, economic, } \\
\text { ethnicity influence outcomes and } \\
\text { perspectives? }\end{array}$ & 5 & 3 & \\
\hline \multicolumn{4}{|l|}{$\begin{array}{l}\text { In teaching and supporting learning: to what } \\
\text { extent does your programme }\end{array}$} \\
\hline $\begin{array}{l}\text { 6. have an engagement strategy that follows } \\
\text { up those not attending or engaging? }\end{array}$ & 7 & 1 & \\
\hline $\begin{array}{l}\text { 7. ensure that allocation of students to small } \\
\text { group work enables the creation of ethnically- } \\
\text { diverse groups from different educational } \\
\text { backgrounds? }\end{array}$ & 1 & 2 & 5 \\
\hline $\begin{array}{l}\text { 8. encourage discussion from students with } \\
\text { diverse backgrounds and include topics } \\
\text { where personal experience and views are } \\
\text { expressed? }\end{array}$ & 5 & 3 & \\
\hline \multicolumn{4}{|l|}{$\begin{array}{l}\text { Assessment: to what extent does your } \\
\text { programme }\end{array}$} \\
\hline $\begin{array}{l}\text { 9. offer a variety of forms of assessments } \\
\text { ensuring that all students have the chance to } \\
\text { practise new forms of assessments? }\end{array}$ & 4 & 3 & 1 \\
\hline $\begin{array}{l}\text { 10. offer formative assessments before all } \\
\text { summative assessments, ensuring that all } \\
\text { students have the chance to practise new } \\
\text { forms of assessments? }\end{array}$ & 4 & 4 & \\
\hline 11. offer individualised and peer feedback? & 5 & 3 & \\
\hline $\begin{array}{l}\text { 12. offer opportunities for students to reflect } \\
\text { on feedback and marks? }\end{array}$ & 6 & 2 & \\
\hline $\begin{array}{l}\text { 13. involve students - apart from the ASER } \\
\text { process - in the formative and summative } \\
\text { annual review of your programme looking at } \\
\text { content and attainment from an ethnic } \\
\text { diversity perspective? }\end{array}$ & & 4 & 4 \\
\hline
\end{tabular}




\section{Evidence that ICHC strategies are research-informed}

As in institutions across the UK, the scientific disciplinary background at UCL prompts staff to question approaches to initiatives. Before they embark on the introduction of innovations, they need to know that these are likely to have a positive impact. Small case studies based on qualitative data do not convince. The issue of how steps to close the attainment gap affect the experience and outcomes of all students has also been posed by staff. However, as we have seen from successful outcomes in institutions such as Kingston, approaches which have proved effective in closing attainment gaps often correspond to good practice in teaching and learning in higher education (HE). Practice is considered 'good' if it is effective in enhancing the student experience and if student outcomes improve across the student population. In the context of this project, special attention must above all be devoted to ensuring that those from minorities have full agency and so feel thoroughly welcome and find that the curriculum resonates for them so they can identify with the topics they study.

An outline follows of the elements of the ICHC (UCL BAME attainment project, 2018) in relation to specific teaching, learning and assessment practices. The link between ICHC recommendations and the research evidence is outlined in Table 3. Each ICHC element is linked to a specific area of evidence. The research evidence derives from studies which disregard student ethnicity, so the Table 3 data answer staff questions concerning the wider impact of the initiatives promoted through $\mathrm{ICHC}$ guidance. The table has been sent to staff with queries about the underpinning of ICHC dimensions in the research into teaching and learning in HE and used at staff development sessions where staff plan actions they would like to take to increase the inclusiveness of their curricula.

The research evidence on the impact of instructional practices in Table 3 is drawn from a synthesis of ' 3,330 effect sizes from quantitative empirical studies involving a total of 1,920,239 students' in HE (Schneider and Preckel, 2017, p.592). Schneider and Preckel's systematic review confirms that '[The] effectivity of courses is strongly related to what teachers do' (op.cit., p.592) and that 'the choice of teaching methods has substantial effects on achievement' (op.cit., p.593), which is important for steps to close the attainment gap. They conclude that their findings '[emphasise] the importance of teacher training in higher education' (op.cit., p.596). A brief overview with related resources has been published by UCL Teaching and Learning (2019).

The evidence in Table 3 (data derived from Schneider and Preckel, op.cit., Table 2, pp.568581) starts with initiatives with the strongest positive effect. The authors point out that even initiatives with a small effect size make a difference to student learning (op.cit., p.592), harmonising with Angel Rose's comment that 'small changes can make all the difference to the students accessing the course' (Rose, 2019). Explanatory comments on Schneider and Preckel's study have been added in italics (see Table 3).

Table 3 also includes mapping to the relevant dimensions ${ }^{3}$ of the UK Professional Standards Framework (UKPSF) for teaching and supporting learning in HE (Higher Education Academy, 2011). The rationale for this addition is that the UKPSF reflects the activities, knowledge and values which underpin our pedagogical choices. This will be familiar to those

3 The UKPSF dimensions overlap. Subject knowledge informs teaching and assessment and values influence choices of approach. Primary dimensions have been mapped in the table, but additional dimensions are also relevant. 
who already hold Advance HE Fellowships based on the appropriate UKPSF descriptor criteria. Fellows will recognise how their work to close the attainment gap constitutes a powerful indicator of remaining in good standing, observing the Advance HE 'Code of Practice' (Higher Education Academy, 2013). The UKPSF is also relevant to staff who are applying for Fellowships, as they will recognise how their efforts to end disadvantage for black, Asian and minority students provide strong examples of effective practice to include in their applications.

Although the BAME Attainment Project at UCL is relatively new, there are signs of the potential for a favourable impact, based on ICHC feedback from many departments. One department has already managed to cut the gap from $3 \%$ to $0.3 \%$. It remains to be seen how black, Asian and minority ethnic students themselves regard these first steps. If BAME students neither benefit nor achieve their potential, we will have to seek new ways of approaching the burning issue of unfair outcomes. We do not accept the attainment gap and are determined, in partnership with students, to close it.

\section{Summary and conclusion}

This article has outlined the multi-level approach of UCL in its efforts to close the BAME attainment gap. We have drawn on and adapted the initiatives of our Catalyst Project partner institutions, engaging staff in working with all students to enhance the experience of BAME groups. We have benefited greatly from the support and advice of senior management and the UCL committee structure.

The focus here started with an overview of research carried out by the UCL Centre for Teaching and Learning Economics, applying decomposition techniques to student degree outcomes data. A study of the ICHC followed, including an example of how departments in one faculty responded, reflecting their perceptions of the current status of their approaches to the curriculum; learning, teaching and assessment; and student support. The elements of the ICHC are examined in light of evidence from a large-scale systematic review of research into learning, teaching, assessment and student support and learning environments. The results are promising.

This account depicts early steps. We have generated a strong awareness about and interest in eliminating the BAME attainment gap across UCL. We are further exploring the experience of BAME students to determine the nuances of the quality of their experience in an effort to ensure that we pinpoint the most effective ways of empowering them to achieve their full potential. 
Table 3. Systematic review evidence (Schneider and Preckel 2017) ${ }^{4}$ related to the Inclusive Curriculum Health Check (ICHC) UKPSF mapping: The overarching Professional Value is 1: 'Respect individual learners and diverse learning communities'.

\begin{tabular}{|c|c|c|c|}
\hline Area and category & Definition with explanation & Cohen's d $\mathrm{d}^{5}$ & Annotated summary of related ICHC guide items \\
\hline $\begin{array}{l}\text { Instruction: assessment } \\
\text { UKPSF mapping } \\
\text { Area of Activity } 3 \\
\text { Assess and give } \\
\text { feedback to learners }\end{array}$ & $\begin{array}{l}\text { Student peer assessment } \\
\text { Peers grade a student's achievement } \\
\text { in addition to the teacher-given grade } \\
\text { High effect size indicates high } \\
\text { similarity showing that students can } \\
\text { assess the quality of peers' work so } \\
\text { have insight into learning } \\
\text { requirements for a successful } \\
\text { outcome }\end{array}$ & 1.91 & $\begin{array}{l}\text { Offer individualised and peer feedback } \\
\text { Peer feedback is based on the assessment of work (any } \\
\text { assessment task appropriate to the relevant module) } \\
\text { Peer assessment of drafts has proved to have a strong } \\
\text { positive impact on student outcomes at UCL. } \\
\text { See, for example: https://www.ucl.ac.uk/teaching- } \\
\text { learning/case-studies/2013/aug/peer-review-virology-essays }\end{array}$ \\
\hline $\begin{array}{l}\text { Student motivation } \\
\text { UKPSF mapping } \\
\text { Area of Activity } 3 \\
\text { Assess and give } \\
\text { feedback to learners }\end{array}$ & $\begin{array}{l}\text { Performance self-efficacy } \\
\text { Perceptions of academic } \\
\text { performance capability } \\
\text { If students are provided with } \\
\text { feedback which increases their } \\
\text { confidence in their ability to succeed, } \\
\text { they will do better }\end{array}$ & 1.81 & $\begin{array}{l}\text { Offer opportunities for students to reflect on feedback and } \\
\text { marks } \\
\text { Feedback which encourages students to succeed by } \\
\text { clarifying how they can develop their learning and enhance } \\
\text { performance increases motivation }\end{array}$ \\
\hline $\begin{array}{l}\text { Instruction: presentation } \\
\text { UKPSF mapping } \\
\text { Area of Activity } 2 \\
\text { Teach and/or support } \\
\text { learning }\end{array}$ & $\begin{array}{l}\text { Teacher's clarity and } \\
\text { understandableness [sic] } \\
\text { The instructor interprets abstract } \\
\text { ideas and theories clearly ... The } \\
\text { instructor makes good use of } \\
\text { examples and illustrations to get } \\
\text { across difficult points }\end{array}$ & 1.35 & $\begin{array}{l}\text { Have reading lists and resources that contain a diverse } \\
\text { range of authors including those from different ethnicities, } \\
\text { from outside the } \\
\text { UK and from non-academic sources where relevant } \\
\text { A diverse range of resources broadens scope for the use of } \\
\text { examples and illustrations which resonate with all students }\end{array}$ \\
\hline Student strategies & Frequency of class attendance & 0.98 & $\begin{array}{l}\text { Have an engagement strategy that follows up on those not } \\
\text { attending or engaging }\end{array}$ \\
\hline
\end{tabular}

${ }^{4}$ Psychological Bulletin impact factor 2017: 13,250

${ }^{5}$ Cohen's $d-(d=$ deviation) 0.2 is a small effect size, 0.50 is a medium effect size, and 0.80 or more is a large effect size.

Schneider and Preckel explain: "The results of original empirical studies with different measures can be synthesized in a meta-analysis by considering a standardized index of the effect size instead of the absolute values that were measured. Many studies use Cohen's $d$ as the standardized effect size index,' (op.cit., p.566). They provide references for further detail on Cohen's $d$. 


\begin{tabular}{|c|c|c|c|}
\hline $\begin{array}{l}\text { UKPSF mapping } \\
\text { Area of Activity } 4 \\
\text { Develop effective } \\
\text { learning environments } \\
\text { and approaches to } \\
\text { student support and } \\
\text { guidance }\end{array}$ & & & $\begin{array}{l}\text { Time spent supporting students who do not attend face-to- } \\
\text { face sessions or engage in online activities is well spent in } \\
\text { terms of enhancing student outcomes }\end{array}$ \\
\hline $\begin{array}{l}\text { Instruction: assessment } \\
\text { UKPSF mapping } \\
\text { Area of Activity } 3 \\
\text { Assess and give } \\
\text { feedback to learners }\end{array}$ & $\begin{array}{l}\text { Student self-assessment } \\
\text { Students grade their own } \\
\text { achievement in addition to teacher- } \\
\text { given grades } \\
\text { High effect size indicates high } \\
\text { similarity showing that students can } \\
\text { assess the quality of their own work } \\
\text { so have insight into learning } \\
\text { requirements for a successful } \\
\text { outcome }\end{array}$ & 0.85 & $\begin{array}{l}\text { Offer opportunities for students to reflect on feedback and } \\
\text { marks } \\
\text { Self-assessment deepens insight into feedback and marks }\end{array}$ \\
\hline $\begin{array}{l}\text { Instruction: presentation } \\
\text { UKPSF mapping } \\
\text { Core Knowledge } 1 \\
\text { The subject material }\end{array}$ & $\begin{array}{l}\text { Teacher's stimulation of interest in } \\
\text { the course and its subject matter } \\
\text { The instructor puts materials across } \\
\text { in an interesting way; the teacher } \\
\text { stimulated intellectual curiosity }\end{array}$ & 0.82 & $\begin{array}{l}\text { All items under 'content', for example, 'Allow students to gain } \\
\text { an understanding of how different factors, e.g. social, } \\
\text { economic, ethnicity, influence outcomes and perspectives' } \\
\text { Relating course content to the real world including diversity } \\
\text { and the consideration of inclusive approaches to ethnicity } \\
\text { stimulates intellectual curiosity }\end{array}$ \\
\hline $\begin{array}{l}\text { Instruction: social } \\
\text { interaction } \\
\text { UKPSF mapping } \\
\text { Core Knowledge } 3 \\
\text { How students learn, both } \\
\text { generally and within their } \\
\text { subject/disciplinary } \\
\text { area(s) }\end{array}$ & $\begin{array}{l}\text { Teacher's encouragement of } \\
\text { questions and discussion } \\
\text { The instructor was willing to help } \\
\text { students having difficulty; the teacher } \\
\text { was accessible to students outside } \\
\text { class }\end{array}$ & 0.77 & $\begin{array}{l}\text { Encourage discussion from students with diverse } \\
\text { backgrounds and include topics where personal experience } \\
\text { and views are expressed } \\
\text { Learners' personal experience and views enable the teacher } \\
\text { to evaluate development and progress and identify students } \\
\text { in difficulty }\end{array}$ \\
\hline
\end{tabular}

Compass: Journal of Learning and Teaching, Vol 12, No 1, 2019 


\begin{tabular}{|c|c|c|c|}
\hline $\begin{array}{l}\text { Instruction: stimulating } \\
\text { meaningful learning } \\
\text { UKPSF mapping } \\
\text { Area of Activity } 1 \\
\text { Design and plan learning } \\
\text { activities and/or } \\
\text { programmes of study }\end{array}$ & $\begin{array}{l}\text { Clarity of course objectives and } \\
\text { requirements } \\
\text { The purpose and policies of the } \\
\text { course were made clear to the } \\
\text { student; the teacher clearly defined } \\
\text { student responsibilities in the course }\end{array}$ & 0.75 & $\begin{array}{l}\text { Overarching aim to 'improve the experience, skills and } \\
\text { attainment of } \\
\text { all students' } \\
\text { If students have the opportunity to gain insight into } \\
\text { module/programme purposes and policies, they have a } \\
\text { better chance of doing well }\end{array}$ \\
\hline $\begin{array}{l}\text { Instruction: social } \\
\text { interaction } \\
\text { UKPSF mapping } \\
\text { Core Knowledge } 3 \\
\text { How students learn, both } \\
\text { generally and within their } \\
\text { subject/disciplinary } \\
\text { area(s) }\end{array}$ & $\begin{array}{l}\text { Open-ended questions } \\
\text { These require students to manipulate } \\
\text { information to create and support a } \\
\text { response } \\
\text { Closed questions in contrast call for } \\
\text { verbatim recall or recognition of } \\
\text { factual information }\end{array}$ & 0.73 & $\begin{array}{l}\text { Create opportunities to discuss different perspectives within } \\
\text { and outside the UK related to ethnic diversity } \\
\text { Open-ended questions framed to explore different } \\
\text { perspectives have a positive impact on learning }\end{array}$ \\
\hline $\begin{array}{l}\text { Instruction: stimulating } \\
\text { meaningful learning } \\
\text { UKPSF mapping } \\
\text { Professional Value } 2 \\
\text { Promote participation in } \\
\text { higher education and } \\
\text { equality of opportunity } \\
\text { for learners }\end{array}$ & $\begin{array}{l}\text { Teacher relates content to students } \\
\text { New information is presented in a } \\
\text { way that explicitly relates it to the } \\
\text { students (self-reference effect) } \\
\text { It is particularly important to be } \\
\text { aware of all student groups when } \\
\text { providing opportunities for learners to } \\
\text { benefit from the self-reference effect }\end{array}$ & 0.65 & $\begin{array}{l}\text { All items on content, for example: } \\
\text { Use material that explores different data, models and } \\
\text { theories related to ethnic diversity - even within an historical } \\
\text { context } \\
\text { Students are better able to engage with new content if it } \\
\text { relates to them; exploring different data will enable more } \\
\text { students to enhance their learning through self-reference }\end{array}$ \\
\hline $\begin{array}{l}\text { Instruction: small group } \\
\text { learning } \\
\text { UKPSF mapping } \\
\text { Area of Activity } 1 \\
\text { Design and plan learning } \\
\text { activities and/or } \\
\text { programmes of study }\end{array}$ & $\begin{array}{l}\text { Small groups of two to ten students } \\
\text { work together toward a common goal } \\
\text { Group work increases opportunities } \\
\text { for discussion and exploration as } \\
\text { well as learning from peers }\end{array}$ & 0.51 & $\begin{array}{l}\text { Ensure that allocation of students to small group work } \\
\text { enables the creation of ethnically-diverse groups from } \\
\text { different educational } \\
\text { backgrounds } \\
\text { Diverse groups lead to enriched learning opportunities } \\
\text { because a range of possible approaches to reaching } \\
\text { common goals will emerge }\end{array}$ \\
\hline
\end{tabular}




\begin{tabular}{|c|c|c|c|}
\hline $\begin{array}{l}\text { Instruction: academic } \\
\text { skills } \\
\text { Professional Value } 4 \\
\text { Acknowledge the wider } \\
\text { context in which higher } \\
\text { education operates } \\
\text { recognising the } \\
\text { implications for } \\
\text { professional practice }\end{array}$ & $\begin{array}{l}\text { Interventions which directly target the } \\
\text { skills and knowledge deemed } \\
\text { necessary for students to } \\
\text { successfully perform [at university] } \\
\text { Can be extracurricular or integrated } \\
\text { into module/programme learning } \\
\text { Adequate preparation for diverse } \\
\text { assessment tasks }\end{array}$ & 0.48 & $\begin{array}{l}\text { Offer a variety of forms of assessments ensuring that all } \\
\text { students have the chance to practise new forms of } \\
\text { assessments } \\
\text { Variety in assessment tasks enables students to develop } \\
\text { skills and knowledge, play to their strengths, and counteract } \\
\text { any weaker areas }\end{array}$ \\
\hline $\begin{array}{l}\text { Instruction: social } \\
\text { interaction } \\
\text { UKPSF mapping } \\
\text { Area of Activity } 4 \\
\text { Develop effective } \\
\text { learning environments } \\
\text { and approaches to } \\
\text { student support and } \\
\text { guidance }\end{array}$ & $\begin{array}{l}\text { Teacher's concern and respect for } \\
\text { students, friendliness } \\
\text { The teacher was friendly toward all } \\
\text { students; the teacher took students } \\
\text { seriously } \\
\text { An approachable teacher who is } \\
\text { concerned that all students should } \\
\text { do well creates a positive learning } \\
\text { environment. }\end{array}$ & 0.47 & $\begin{array}{l}\text { Overarching aim to '[ensure] that all students, regardless of } \\
\text { background, are able to participate fully and achieve at equal } \\
\text { rates' } \\
\text { Concern and respect for all students create an environment } \\
\text { which is conducive to learning for all } \\
\\
\text { Respect for students is also conveyed by involving students } \\
\text { in the formative and summative annual review of your } \\
\text { Programme, looking at content and attainment from an } \\
\text { ethnic diversity perspective }\end{array}$ \\
\hline
\end{tabular}




\section{Reference list}

Adams, R. (2018) 'UK universities making slow progress on equality, data shows.' The Guardian, 7 September 2018. Available at:

https://www.theguardian.com/education/2018/sep/07/uk-university-professors-black-minorityethnic (Accessed: 8 May 2019).

Arthur, M. (2019) Provost's View: Equality, Diversity and Inclusion at UCL - challenging unacceptable behaviour and attitude. Available at: https://uclnews.org.uk/t/UAA-65H50BBUGAA3A64/cr.aspx (Accessed: 27 April 2019).

Chaudhury, P., Buttle, H., Hao, O., Topetta, A. (2019) The BAME Attainment Gap - Sources and implications for the (academic) pipeline. Teaching and Learning Seminar, Department of Economics, University of Warwick, 8 May 2019. Available at:

https://warwick.ac.uk/fac/soc/economics/seminars/?calendarltem=8a17841b65e801fc016638e fc17d15c5 (Accessed: 8 May 2019).

Duhs, R. (2019) Closing the attainment gap: why an inclusive curriculum makes a difference to all students (in UCL Teaching and Learning). Available at: https://www.ucl.ac.uk/teachinglearning/news/2019/mar/closing-attainment-gap-why-inclusive-curriculum-makes-differenceall-students (Accessed: 27 April 2019).

Fairlie, R. (2003) An Extension of the Blinder-Oaxaca Decomposition Technique to Logit and Probit Models. Available at: http://www.econ.yale.edu/growth pdf/cdp873.pdf (Accessed: 8 May 2019).

Higher Education Academy (2011) UK Professional Standards Framework for teaching and supporting learning in higher education (UKPSF). Available at:

https://www.heacademy.ac.uk/system/files/downloads/UK Professional Standards

Framework.pdf (Accessed: 27 April 2019).

Higher Education Academy (2013) Fellowship of the Higher Education Academy: Code of Practice. Available at:

https://www.heacademy.ac.uk/system/files/downloads/Code Of Practice.pdf (Accessed: 27 April 2019).

McDuff, N. (2019) 'Preface'. Compass: Journal of Learning and Teaching, 12(1). In Press.

McDuff, N., Tatam, J., Beacock, O. and Ross, F. (2018) 'Closing the attainment gap for students from black and minority ethnic backgrounds through institutional change.' Widening Participation and Lifelong Learning, 20(1), 79-101. Available at: https://www.ingentaconnect.com/content/openu/jwpll/2018/00000020/00000001/art00005;jses sionid=2frlxw4 mupdfm.x-ic-live-02 (Accessed: 29 May 2019).

Rose, Angel (2019) quoted in Walker, S., Editorial. Compass Journal of Learning and Teaching, Current Special Issue.

Owen, Derfel (2015) Spotlight on: the Annual Student Experience Review (ASER) process. Available at: https://www.ucl.ac.uk/teaching-learning/news/2015/sep/spotlight-annual-studentexperience-review-aser-process (Accessed: 27 April 2019). 
Schneider, M. and Preckel, F. (2017) Variables associated with achievement in higher education: A systematic review of meta-analyses. Psychological Bulletin, 143(6), 565-600. Available at: http://dx.doi.org/10.1037/bul0000098 (Accessed: 20 January, 2019).

Sedghi, G. and Rushworth, E. (2017) 'The relation between multi-cultural group work and the integration of home and international students.' New Directions in the Teaching of Physical Sciences, 12(1). Available at: https://journals.le.ac.uk/ojs1/index.php/newdirections/article/view/857?acceptCookies=1 (Accessed: 29 May 2019).

UCL BAME Attainment Project (2018) Inclusive Curriculum Health Check. Available at: https://www.ucl.ac.uk/teaching-learning/sites/teachinglearning/files/ucl inclusive curriculum healthcheck 2018.pdf (Accessed: 27 April 2019).

UCL Teaching and Learning (2017) New analysis confirms existence of attainment gap for BAME students at UCL. Available at: https://www.ucl.ac.uk/teachinglearning/news/2017/dec/new-analysis-confirms-existence-attainment-gap-BAME-students-ucl (Accessed: 27 April 2019).

UCL News (2019) Inquiry launches into history of eugenics at UCL. Available at: https://uclnews.org.uk/t/UAA-65H50-BBUGAA3A64/cr.aspx (Accessed: 27 April 2019). 